\title{
ADMINISTRATION OF JUSTICE IN ENGLAND 1906 v. 1923
}

\section{W. JETHRO BROWN}

To a lawyer of today who returns to London, after I7 years exile in a remote province of the Empire, the Judiciary, the Procedure, and Practice of the Law Courts display changes of some interest.

The more obvious changes may be generalized as a greater elasticity of form, and some waning in the importance of precedent. Incidentally, a greater freedom in the amendment of pleadings, a more evident desire to do justice as between particular litigants before the Court.

Many years ago a learned writer predicted that the distinction between the rigid administration of Justice in England on the principle of stare decisis in contrast with the comparative deference in France to la doctrine, would probably admit of attenuation in the course of time. I cannot say what has happened to la doctrine in France. But it does appear to me that in England prediction is verified. Of course precedents bind! But there appears to me a more evident desire and/or ingenuity in distinguishing a precedent from the complexus of facts before the Court if the application of precedent might lead to inconvenient consequence. I am not concerned with merits but with phenomena. But I may be allowed to comment that, whilst a certain responsiveness of judicial decision to changing social and economic conditions is desirable, the degree of that responsiveness is a matter of concern. I confess myself apprehensive. This may be partly temperamental. In the first place, in humble concurrence with a famous Frenchman, I distrust facts. They so often, viewed in a way atomistic, mislead and so dethrone Truth. I like the "facts of a case" to be determined, one way or the other, as nearly as possible, and as speedily as possible. The mind is then emancipate. It can embark upon the more congenial task of settling the law applicable. It may seem a harsh thing to say; but it is well to be candid. The unhappy litigant is, in a very real sense, a means to an end. Caught in the grim clutch of the law, he is well on the way to serve far higher purposes than just that of securing what he deems justice for himself. I follow humbly Kant in holding that no man should be treated merely as means to an end. I only seek to put a due emphasis on the word "merely." A litigant before the Court is a party, not only in the case, but also in the endeavor of a society to work towards the goal of a coherent body of doctrine. My mental attitude may be due, as I have suggested, to temperament. It may be due to academic training. What I desire to emphasise is that, in my opinion, there has been a quite observable 
tendency, during the last two decades, for the British Bench to interpret and apply justice with reference to "the merits of the case" without an adequate consideration of the effects of decision upon an already chaotic body of law.

Causation deserves consideration. In the first place, the terrifying increase of law, the ever increasing growth of the jungle of statute and precedent, may well drive a judge towards the goal of "dealing with a case on its merits." Judges, like ordinary mortals, may not unnaturally say, consciously or unconsciously, "The law is a tangle. Let us look dispassionately at the facts of the case." Of course, stare decisis. But as precedents in Courts of Common Law accumulate with bewildering rapidity throughout the English-speaking world, the temptation to "distinguish" so as to meet the facts of any given case in accordance with "instincts of justice" may easily become irresistible, and enthrone caprice in the place of principle. In the second place, the bewildering rapidity of change in the social and economic milieu affect the judicial as well as the lay mind. The implication should be obvious. A period of rapid transitions may well affect the judicial temper in the direction of an excessive concentration upon the special facts of a problem submitted for adjudication.

I note in the method of the administration of justice a greater freedom on the part of judges in interrupting counsel, sometimes by suggestions, sometimes by submitting "posers." Whether in an origiral or appellate jurisdiction, the Court of Justice has sometimes suggested to my mind the Round Table Conference. The Bar may not like the change. Its members can hardly be unconscious of it. The tide of forensic eloquence is stemmed by questions which embarrass or disconcert. It must be rather an ordeal for an advocate, with a supply of well prepared and graceful periods, calculated to impress at least his client, if not the Court, to have to submit to such curt questions as "Do you really mean to argue that," etc., or "You surely do not suppose that," etc. Or, again, "Is your argument designed to prove the superfluous (or it may be the impossible) position?" And so on. I venture to express the opinion that the changed attitude tends to expedition in the administration of justice.

One consequence, if not exasperating to the Bench and Bar, must be at least exacting to the patience of the student who may attend Courts of Jústice for the purpose of legal training. When a judgment turns largely on the particular facts of a case, by almost inevitable sequence, the argument and decisions of appellate tribunals are infused with elements of "fact" which the student might be pardoned for hoping would have been settled by the Judge in the first instance. in a number of recent Appeals, both before the House of Lords and the Privy Council, I had reason for amazement at the extent to which "facts" have had to be decided upon, directly or indirectly. 
A long standing grievance, though still remaining, is in some - respects less troubling to the wearied mind. I long deplored the failure of the British Bench to adopt the practice of the Supreme Court of the United States as regards a single majority judgment. While the facts in two cases may be the same, "the merits of the case" are never the same. In proportion as "merits" dethrone or tend to dethrone principle, a judge of an inferior court is the less worried by attempts to obtain a composite photograph of a number of judgments of a superior court, whether leading to the same or a different conclusion. When a thing is impossible, why worry? This is said in no disrespect. It is a mere expression of a feeling that every cloud has a silver lining. 